\title{
Further Evidence for Veridical Perception During Near-Death Experiences
}

\author{
Kenneth Ring, Ph.D. \\ University of Connecticut \\ Madelaine Lawrence, R.N., Ph.D. \\ Hartford Hospital, Hartford, CT
}

ABSTRACT: We briefly survey research designed to validate alleged out-ofbody perceptions during near-death experiences. Most accounts of this kind that have surfaced since Michael Sabom's work are unsubstantiated selfreports or, as in claims of visual perception of blind persons, completely undocumented or fictional, but there have been some reports that were corroborated by witnesses. We briefly present and discuss three new cases of this kind.

What if you slept, and what if in your sleep you dreamed, and what if in your dream you went to heaven and there plucked a strange and beautiful flower, and what if when you awoke you had the flower in your hand?

Ah, what then?

Samuel Taylor Coleridge

Despite repeated expressions for the need to verify out-of-body perceptions during near-death experiences (NDEs) (for example, Blackmore, 1984, 1985; Cook, 1984; Holden, 1988, 1989; Holden and Joesten,

Kenneth Ring, Ph.D., is Professor of Psychology at the University of Connecticut in Storrs, Connecticut, and Madelaine Lawrence, R.N., Ph.D., is Director of Nursing Research at Hartford Hospital in Hartford, Connecticut. Reprint requests should be addressed to Dr. Ring at the Department of Psychology, University of Connecticut, Storrs, CT 06269-1020. 
1990; Kincaid, 1985; and Krishnan, 1985), the last decade has produced virtually nothing of substance on this vital issue. Michael Sabom's pioneering work (Sabom, 1981, 1982) is now recognized as essentially the only evidence from systematic research in the field of near-death studies that suggests NDErs can sometimes report visual perceptions that are physically impossible and not otherwise explicable by conventional means. To be sure, Sabom's data remain controversial, but the point is that they are still the only extensive body of evidence that bears on the question of veridical perception during near-death states.

Subsequent investigators, such as Janice Miner Holden and Leroy Joesten (1990), have attempted to follow Sabom's lead, but their work has been inconclusive, a casualty of various bureaucratic and methodological complications. What has emerged instead in the aftermath of Sabom's research is largely a miscellany of unsubstantiated selfreports as tantalizing as they are unverifiable. These reports dot the landscape of near-death studies like so many promising trails (for example, Grey, 1985, pp. 37-38; Moody and Perry, 1988, pp. 134-135; and Ring, 1984, pp. 42-44), but efforts to pursue their tracks to definite conclusions almost always prove disappointing. This is particularly true for precisely those cases that hold out the greatest hope for confounding the challenge of skeptics, namely those where blind persons are alleged to have seen accurately during their NDEs.

For example, more than a decade ago, one of us (K.R.) learned of three such elusive cases from Fred Schoonmaker, one of the first physicians to conduct an extensive investigation of NDEs. In a telephone conversation Schoonmaker mentioned that he had come across three blind persons who had furnished him with evidence of veridical visual perceptions while out-of-body, including one woman he said had been congenitally blind. On hearing the details of this last story, I (K.R.) became very excited and urged him to publish an article on these extraordinary NDEs. Regrettably, he never did.

Another example of a blind person purportedly having detailed visual perception during an NDE was described by Raymond Moody and Paul Perry (1988, pp. 134-135). Intrigued to learn more about this case, not long ago I (K.R.) asked Moody to share with me some further particulars about its evidentiality. Unfortunately, he could only tell me that he had learned of this story as a result of another physician's playing a tape about it following one of Moody's lectures. He didn't remember the physician's name and therefore could do no more than relate the brief account his book attested to (R. A. Moody, Jr., personal communication, February, 1991). 
Perhaps the most disappointing outcome of this kind of search was in response to the astonishing case of a woman named Sarah, with which still another physician, Larry Dossey, began a recent book (Dossey, 1989). According to Dossey, Sarah had had a cardiac arrest during gall bladder surgery, but had been successfully resuscitated. Upon recovery she had "amazed the ... surgery team" by reporting

a clear, detailed memory of ... the OR layout; the scribbles on the surgery schedule board in the hall outside; the color of the sheets covering the operating table; the hairstyle of the head scrub nurse ... and even the trivial fact that her anesthesiologist that day was wearing unmatched socks. All this she knew even though she had been fully anesthetized and unconscious during the surgery and the cardiac arrest. But what made Sarah's vision even more momentous was the fact that, since birth, she had been blind. (Dossey, 1989, p. 18)

This sounds like the ideal case of its kind; and that, in a sense, is exactly what it is, in a different sense. Kindly responding to an inquiry for more information about this case, Dossey confessed to me (K.R.) that he had "constructed" it on the basis of a composite description of the out-of-body testimony of NDErs such as that found in Sabom's and Moody's books. With this example we seem to have come full circle, to where the mere lore of NDE veridicality subtly shades into a dangerous self-confirming proposition-and to another dead end.

That skeptical conclusion is the impression left by this cursory review of the cases that have come to light since Sabom's trailblazing efforts. However, there have been some subsequent reports that seem to represent evidence that Dossey's fiction may in the end prove indeed to be substantiated NDE fact: the testimony of NDErs that has been supported by independent corroboration of witnesses.

Perhaps the most famous case of this kind is that of Maria, originally reported by her critical care social worker, Kimberly Clark (1984). Maria was a migrant worker who, while visiting friends in Seattle, had a severe heart attack. She was rushed to Harborview Hospital and placed in the coronary care unit. A few days later she had a cardiac arrest and an unusual out-of-body experience. At one point in this experience, she found herself outside the hospital and spotted a single tennis shoe sitting on the ledge of the north side of the third floor of the building. Maria not only was able to indicate the whereabouts of this oddly situated object, but was able to provide precise details concerning its appearance, such as that its little toe was worn and one of its laces was stuck underneath its heel.

Upon hearing Maria's story, Clark, with some considerable degree of skepticism and metaphysical misgiving, went to the location described 
to see whether any such shoe could be found. Indeed it was, just where and precisely as Maria had described it, except that from the window through which Clark was able to see it, the details of its appearance that Maria had specified could not be discerned. Clark concluded:

The only way she could have had such a perspective was if she had been floating right outside and at very close range to the tennis shoe. I retrieved the shoe and brought it back to Maria; it was very concrete evidence for me. (Clark, 1984, p. 243)

Not everyone, of course, would concur with Clark's interpretation, but assuming the authenticity of the account, which we have no reason to doubt, the facts of the case seem incontestable. Maria's inexplicable detection of that inexplicable shoe is a strange and strangely beguiling sighting of the sort that has the power to arrest a skeptic's argument in mid-sentence, if only by virtue of its indisputable improbability. And yet it is only one case and, however discomfitting to some it might temporarily be, it can perhaps be conveniently filed away as merely a puzzling anomaly, in the hope that some prosaic explanation might someday be found.

Such a response is understandable and seems rational. However, there are more cases like Maria's, and we have found some. Since our search for conclusive cases of blind NDErs had thus far proven unavailing, we directed our efforts to tracking down instances of the "Maria's shoe" variety, where improbable objects in unlikely locations were described by NDErs and where at least one witness could either confirm or disprove the allegation. So far we have found the following three such cases, two of which, oddly enough, involve shoes!

\section{Case One}

In 1985, Kathy Milne was working as a nurse at Hartford Hospital. Milne had already been interested in NDEs, and one day found herself talking to a woman who had been resuscitated and who had had an NDE. Following a telephone interview with me (K.R.) on August 24, 1992, she described the following account in a letter:

She told me how she floated up over her body, viewed the resuscitation effort for a short time and then felt herself being pulled up through several floors of the hospital. She then found herself above the roof and realized she was looking at the skyline of Hartford. She marvelled at how interesting this view was and out of the corner of her eye she saw a red object. It turned out to be a shoe.... [S] 
thought about the shoe . . . and suddenly, she felt "sucked up" a blackened hole. The rest of her NDE was fairly typical, as I remember.

I was relating this to a [skeptical] resident who in a mocking manner left. Apparently, he got a janitor to get him onto the roof. When I saw him later that day, he had a red shoe and became a believer, too. (K. Milne, personal communication, October 19, 1992)

One further comment about this second white crow, again in the form of a single, improbably situated shoe sighted in an external location of a hospital: After my (K.R.) initial interview with Milne, I made a point of inquiring whether she had ever heard of the case of Maria's shoe. Not only was she unfamiliar with it, but she wasutterly amazed to hear of another story so similar to the one she had just recounted for me. It remains an unanswered question how these isolated shoes arrive at their unlikely perches for later viewing by astonished NDErs and their baffled investigators.

\section{Case Two}

In the summer of 1982 , Joyce Harmon, a surgical intensive care unit (ICU) nurse at Hartford Hospital, returned to work after a vacation. On that vacation she had purchased a new pair of plaid shoelaces, which she happened to be wearing on her first day back at the hospital. That day, she was involved in resuscitating a patient, a woman she didn't know, giving her medicine. The resuscitation was successful, and the next day, Harmon chanced to see the patient, whereupon they had a conversation, the gist of which (not necessarily a verbatim account) is as follows (J. Harmon, personal communication, August 28, 1992):

The patient, upon seeing Harmon, volunteered, "Oh, you're the one with the plaid shoelaces!"

"What?" Harmon replied, astonished. She says she distinctly remembers feeling the hair on her neck rise.

"I saw them," the woman continued. "I was watching what was happening yesterday when I died. I was up above."

\section{Case Three}

In the late 1970s, Sue Saunders was working at Hartford Hosnital as a respiratory therapist. One day, she was helping to resuscitate a 60 ish man in the emergency room, whose electrocardiogram had gone flat. Medics were shocking him repeatedly with no results. Saunders 
was trying to give him oxygen. In the middle of the resuscitation. someone else took over for her and she left.

A couple of days later, she encountered this patient in the ICU. He spontaneously commented, "You looked so much better in your yellow top."

She, like Harmon, was so shocked at this remark that she got goosebumps, for she had been wearing a yellow smock the previous day.

"Yeah," the man continued, "I saw you. You had something over your face and you were pushing air into me. And I saw your yellow smock."

Saunders confirmed that she had had something over her face-a mask-and that she had worn the yellow smock while trying to give him oxygen, while he was unconscious and without a heartbeat ( $S$. Saunders, personal communication, August 28, 1992).

\section{Discussion}

The three cases we have presented briefly attest to three important observations: (1) patients who claim to have out-of-body experiences while near death sometimes describe unusual objects that they could not have known about by normal means; (2) these objects can later be shown to have existed in the form and location indicated by the patients' testimony; and (3) hearing this testimony has a strong emotional and cognitive effect on the caregivers involved, either strengthening their pre-existing belief in the authenticity of NDEs or occasioning a kind of on-the-spot conversion.

We are not suggesting, of course, that the cases we have described here constitute proof of the authenticity of NDEs or even that they necessarily demonstrate that patients have been literally out of their bodies when they report what they do. We only submit that such cases add to the mounting evidence that veridical and conventionally inexplicable visual perceptions do occur during NDEs, and the fact of their existence needs to be reckoned with by near-death researchers and skeptics alike.

We hope that our small collection of cases will motivate other investigators to search for and document their own, so that this body of data will increase to the point where it becomes generally accepted, whatever its explanation may ultimately be. Until such time as more studies like those undertaken by Sabom and Holden are actually conducted by near-death researchers, or a genuine case of corroborated visual perception by a blind NDEr is reported, perhaps instances of the kind we have offered here will constitute the strongest argument that 


\section{cases like Dossey's Sarah are by no means as fictional as skeptics might think.}

\section{References}

Blackmore, S. J. (1984). Are out-of-body experiences evidence for survival? Reply to Cook [Letter]. Anabiosis: The Journal of Near-Death Studies, 4, 169-171.

Blackmore, S. J. (1985). Are out-of-body experiences evidence for survival? Reply to Krishnan [Letter]. Anabiosis: The Journal of Near-Death Studies, 5(1), 79-82.

Clark, K. (1984). Clinical interventions with near-death experiencers. In B. Greyson and C. P. Flynn (Eds.), The near-death experience: Problems, prospects, perspectives (pp. 242-255). Springfield, IL: Charles C. Thomas.

Cook, E. W. (1984). Are out-of-body experiences evidence for survival? [Letter]. Anabiosis: The Journal of Near-Death Studies, 4, 167-169.

Dossey, L. (1989). Recovering the soul: A scientific and spiritual search. New York, NY: Bantam.

Grey, M. (1985). Return from death: An exploration of the near-death experience. London, England: Arkana.

Holden, J. M. (1988). Visual perception during the naturalistic near-death out-of-body experience. Journal of Near-Death Studies, 7, 107-120.

Holden, J. M. (1989). Unexpected findings in a study of visual perception during the naturalistic near-death out-of-body experiences. Journal of Near-Death Studies, 7, 155-163.

Holden, J. M., and Joesten, L. (1990). Near-death veridicality research in the hospital setting: Problems and promise. Journal of Near-Death Studies, 9, 45-54.

Kincaid, W. M. (1985). Sabom's study should be repeated [Letter]. Anabiosis: The Journal of Near-Death Studies, 5(2), 84-87.

Krishnan, V. (1985). Are out-of-body experiences evidence for survival? [Letter]. Anabiosis: The Journal of Near-Death Studies, 5(1), 76-79.

Moody, R. A., Jr., and Perry, P. (1988). The light beyond. New York, NY: Bantam.

Ring, K. (1984). Heading toward omega. In search of the meaning of the near-death experience. New York, NY: William Morrow.

Sabom, M. B. (1981). The near-death experience: Myth or reality? A methodological approach. Anabiosis: The Journal of Near-Death Studies, 1, 44-56.

Sabom, M. B. (1982). Recollections of death: A medical investigation. New York, NY: Harper and Row. 